\title{
Does R\&D Matter for Economic Growth or Vice-Versa? An Application to Portugal and Other European Countries
}

\author{
João Filipe Santos \\ Instituto Superior Técnico, Universidade de Lisboa \\ Av. Rovisco Pais, 1049-001 Lisboa, Portugal \\ Margarida Catalão-Lopes \\ CEG-IST and Instituto Superior Técnico, Universidade de Lisboa \\ Av. Rovisco Pais, 1049-001 Lisboa, Portugal \\ mcatalao@tecnico.ulisboa.pt
}

\begin{abstract}
Significant research has studied the impact of Research and Development (R\&D) on Gross Domestic Product (GDP) at the country level. However, few studies consider the possibility that a country's GDP can also be a driver for R\&D. This paper investigates the causal relationship linking R\&D and growth in a sample of European Union (EU) countries, with an emphasis on Portugal. A causal relationship from growth to $R \& D$ can only be proven for France and Spain, whereas the inverse causality only seems to exist for The Netherlands. The co-integration results question the existence of a long-run relationship between R\&D and GDP.
\end{abstract}

Keywords: R\&D, Economic growth, Co-integration, Granger causality, European countries, Portugal.

\section{INTRODUCTION}

Under the European Year of Creativity and Innovation in 2009, an increased emphasis was put in areas that relate with Research and Development (R\&D), innovation, and patents. This effort aimed at contributing to the goal of the March 2000's Lisbon Strategy which intended to make the European Union (EU), by 2010, "the most competitive and dynamic knowledge-based economy in the world, capable of sustainable economic growth with more and better jobs and greater social cohesion."

One of the primary objectives of the Lisbon Strategy - raise overall R\&D investment in Europe to $3 \%$ of gross domestic product (GDP) - was not accomplished, however. Only Finland (3.87\%), Sweden (3.42\%) and Denmark (3.06\%) placed themselves above the 3\% target that was set for 2010, while Germany and Austria were close to it (2.62\% and 2.76\%, respectively). Portugal, with a $1.59 \%$ mark, is one of the EU countries that did not meet the above objective, despite some important progress. From 2000 to 2009 R\&D intensity more than doubled in Portugal, and R\&D spending almost tripled, with a remarkable increase from 2005 onwards. Likewise, the number of researchers in Portugal increased 130\% between 2000 and 2008, largely above the EU average, which was less than $29 \%$.

The current paper is a contribution to the understanding of the relationship between R\&D and macroeconomic performance. The study is applied to the European Union, with a particular 
emphasis being given to Portugal, where investment largely increased in recent years, but GDP did not. The Portuguese evolution is consistent with the "R\&D paradox" (for instance Ejermo et al., 2011) - high and growing levels of R\&D connected with low GDP growth. Based on the outcome of causality and co-integration tests on R\&D and GDP series, we intend to find out which EU countries have the most effective R\&D policies. We focus on the pre- economic and financial crisis period.

The remaining of the paper is structured as follows. Next section provides a review of the most relevant literature on the theme. Section 3 presents the procedures to be employed in our analysis as well as the data. In Section 4 results are extracted. We present the results of stationarity testing, cointegration testing and Granger causality testing. Section 5 summarizes and discusses the main findings.

\section{LITERATURE REVIEW}

In what concerns Portugal, and although there exist some related works, to the best of our knowledge this is the first time that causality between R\&D and GDP is addressed. Previous studies (Teixeira and Fortuna, 2004 and 2010) applied cointegration analysis (to investigate the role of human capital in Portuguese economic growth), but did not inspect causality. Tavares (2004) and Cavalcanti and Novo (2005) analysed the relationship between Portuguese institutions and economic growth, concluding that Portuguese legal and financial institutions should be reformed in order to enhance the catch-up process to other more developed EU countries. The findings of Teixeira (2007) and Barbosa and Faria (2011) go in the same direction. Despite the relatively vast literature on the Portuguese case, research on the causal relationship between $R \& D$ spending and economic growth by using time series analysis is still needed.

The neoclassical growth theory postulates that technological progress is exogenous and proceeds at a steady rate, with technology falling as "manna from heaven". The endogeneization of technological progress with the seminal works of Romer (1986) and Lucas (1988) was an important step forward. Many models have since then dealt with endogenous growth focusing on profit-seeking research as an important source of technological progress and economic growth. The growth rate of ideas is a positive function of the number of researchers and an increase in the current stock of ideas leads to an increase in productivity. This implies that countries with more researchers should have faster growth rates. The empirical evidence, however, sometimes seems to contradict this implication. The well-known Jones (1995) critique to Schumpeterian models points out the fact that R\&D has increased enormously in the post war period with no tendency for productivity to rise - R\&D paradox. To reconcile Schumpeterian growth with evidence, and among other attempts, a recent article by Ertur and Koch (2011) proposes that the cross-country interdependence generated by international R\&D spillovers is taken into account when testing the role of R\&D in the long-run growth process (see also Scopelliti, 2010 for a survey on recent models of competition and Schumpeterian growth). The directionality, however, is just from R\&D to GDP, falling to consider the reverse (from GDP to R\&D), which we also address.

Even though, as we said, the empirical outlook on the relation between R\&D investment and economic growth has been mostly unidirectional, there are some studies attempting to cover the possible two-way causality between R\&D and economic output (e.g. Bravo-Ortega and Marín, 2011, Coada and Rao, 2008). Directly connected with our paper, Wu et al. (2007) examine the causality pattern in R\&D expenditure and economic growth. By using an error correction model (ECM), testing for Granger causality and analysing the impulse response in a 
study applied to China, the authors conclude that there is a long-run co-integration relationship between R\&D and GDP and a bidirectional causal relationship.

The present paper is a further input to the comprehension of the role of R\&D on economic growth and vice-versa. In the current paper, the co-integration and Granger causality tests for Portugal fail to prove that increased R\&D investment engenders increased economic growth and/or vice-versa. However, for other countries such as France and Spain, a Granger causal relationship running from GDP growth to R\&D growth can be proven. For the Netherlands, a unidirectional causal link running from R\&D investment to GDP growth is found.

\section{DATA AND APPROACH}

The main objective of this paper is to analyse the existing relationship between $R \& D$ investment and economic growth for the EU, with a special focus on Portugal. Econometric tools such as co-integration analysis and Granger causality testing are adequate for this purpose. If there is a co-integration vector linking R\&D effort and economic growth, there is causality among these variables in at least one direction, and a stable long-run relationship between the two. Building on these tests, it is possible to tell whether R\&D investment causes economic growth or the reverse (or both - bidirectional causality). The outcome drawn is confronted with the European Union's reality vis-à-vis R\&D policies.

We use annual OECD data for GDP and R\&D, covering 22 observations, from 1987 to 2008, the pre-crisis period. This is a short sample, which will require the use of small sample critical values. The raw time series come in million US \$, at constant PPP's. For the GDP time series, the reference year is 2005 , whereas for the $R \& D$ data the reference year is 2000 . The fact that the series are at a different base year does not influence the results, as what is being tested is the correlation and interdependence of both variables. Besides Portugal, the analysis focuses on Germany, France, the Netherlands, Spain, the United Kingdom, Belgium and Ireland.

Using the natural logarithm of the data, the series will be tested for stationarity, through the analysis of the respective graphs, correlograms and Augmented Dickey-Fuller tests (Dickey and Fuller, 1981). Based on these results, the series will be "detrended" by using the first difference. Moreover, the Johansen (1991) co-integration test will be computed (after having previously confirmed residual normality). Finally, the Granger causality test will also be performed in order to check the nature of the causal relationship that may link R\&D spending and GDP.

\section{Stationarity tests \\ Portugal}

One of the main reasons for a spurious correlation is caused by non-stationary time series. Before assuming any causality between the GDP and R\&D variables, both series need to be checked for whether they are stationary or not. A stationary time-series is one whose basic properties do not change over time. On the contrary, a non-stationary variable has usually ascending or descending trend. As a matter of fact, Figure 1 appears to show an upward trend over time for both variables depicted, Portugal's GDP and R\&D, both in logarithms.

The two series increase at rather different rates, with R\&D spending growing at a higher pace than GDP, especially from 2004 onwards. This structural break implies a significant deviation from the previous mean. The explanation for this major trend change can be the massive public 
R\&D investment in 2005. Actually, in order to comply with the previous Lisbon Strategy and EU2020 3\% target, R\&D spending in Portugal almost tripled from 2005 to 2008.

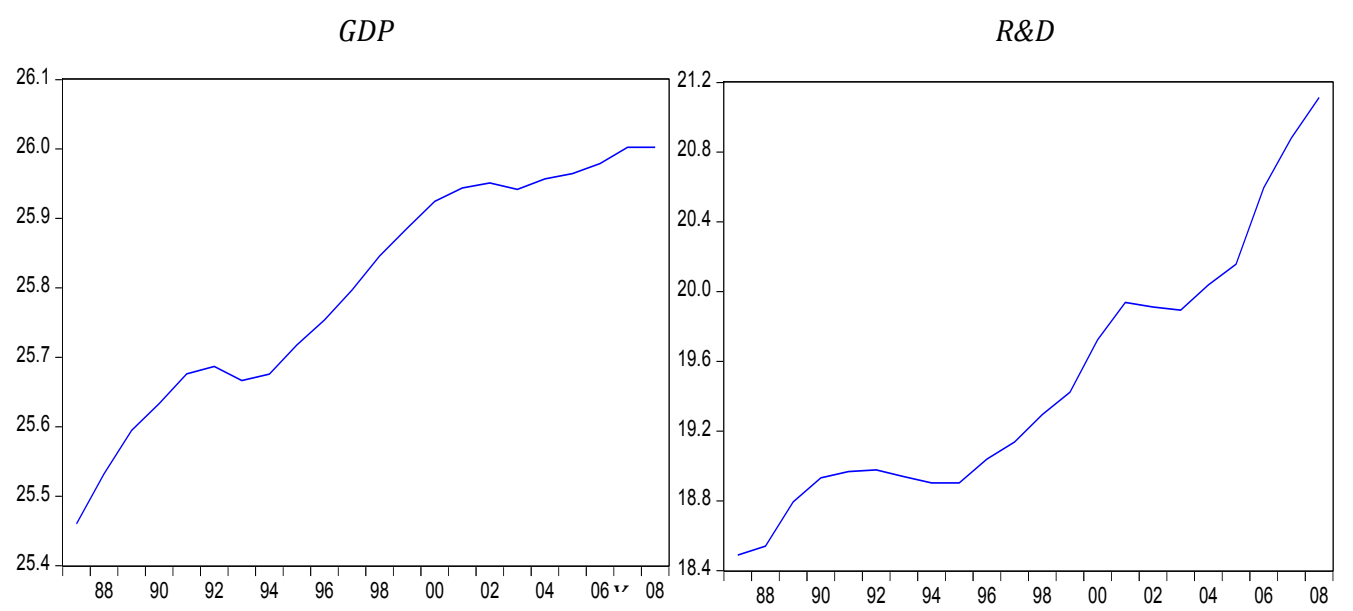

Figure 1 - Portugal's GDP and R\&D expenditure in Industry from 1987 to 2008 (logarithm)

The analysis of the correlograms suggests that the series are non-stationary, as the autocorrelation values are always significantly positive and decrease in a geometrical fashion (see Figures 2 and 3 below).

Sample: 19872008

Included observations: 22

\begin{tabular}{|c|c|c|c|c|c|c|c|c|}
\hline \multicolumn{2}{|c|}{ Autocorrelation } & \multicolumn{3}{|c|}{ Partial Correlation } & \multirow{2}{*}{$\frac{\mathrm{AC}}{20.844}$} & \multirow{2}{*}{$\begin{array}{l}\text { PAC } \\
0.844\end{array}$} & \multirow{2}{*}{$\frac{\text { Q-Stat }}{17.910}$} & \multirow{2}{*}{$\frac{\text { Prob }}{0.000}$} \\
\hline 1 & & 1 & & 1 & & & & \\
\hline $\mathbf{I}$ & $\square$ & 1 & 1 & 2 & 0.698 & -0.051 & 30.758 & 0.000 \\
\hline 1 & $\square$ & 1 & 1 & 3 & 0.573 & -0.008 & 39.894 & 0.000 \\
\hline 1 & $\square$ & $\mathbf{I}$ & 1 & 4 & 0.459 & -0.040 & 46.084 & 0.000 \\
\hline 1 & וב & 1 & 1 & 5 & 0.362 & -0.013 & 50.164 & 0.000 \\
\hline 1 & 1 & 1 & 1 & 6 & 0.268 & -0.060 & 52.526 & 0.000 \\
\hline 1 & 1 & । 口 & I & 7 & 0.141 & -0.179 & 53.228 & 0.000 \\
\hline 1 & 1 & 1 마 & 1 & 8 & 0.004 & -0.150 & 53.228 & 0.000 \\
\hline 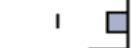 & 1 & 의 & 1 & 9 & -0.122 & -0.101 & 53.833 & 0.000 \\
\hline $1 \square$ & 1 & 논 & 1 & 10 & -0.234 & -0.100 & 56.237 & 0.000 \\
\hline $1 \square$ & 1 & 1 & 1 & 11 & -0.325 & -0.079 & 61.303 & 0.000 \\
\hline$\square$ & 1 & 1 & 1 & 12 & -0.383 & -0.020 & 69.042 & 0.000 \\
\hline
\end{tabular}

Figure 2 - Correlogram of GDP (Portugal) 
Sample: 19872008

Included observations: 22

\begin{tabular}{|c|c|c|c|c|c|c|c|c|}
\hline \multicolumn{2}{|c|}{ Autocorrelation } & \multicolumn{3}{|c|}{ Partial Correlation } & \multirow{2}{*}{$\frac{A C}{0.816}$} & \multirow{2}{*}{$\frac{\text { PAC }}{0.816}$} & \multirow{2}{*}{$\frac{\text { Q-Stat }}{16.761}$} & \multirow{2}{*}{$\frac{\text { Prob }}{0.000}$} \\
\hline 1 & & 1 & & 1 & & & & \\
\hline 1 & $\square$ & 1 & 1 & 2 & 0.630 & -0.109 & 27.251 & 0.000 \\
\hline 1 & & 1 & I & 3 & 0.480 & -0.006 & 33.646 & 0.000 \\
\hline 1 & & I & I & 4 & 0.389 & 0.076 & 38.084 & 0.000 \\
\hline 1 & & 1 & 1 & 5 & 0.308 & -0.041 & 41.026 & 0.000 \\
\hline 1 & 1 & 1 & 1 & 6 & 0.235 & -0.019 & 42.848 & 0.000 \\
\hline 1 & 1 & 1 & I & 7 & 0.137 & -0.116 & 43.512 & 0.000 \\
\hline 1 & 1 & । 口 & I & 8 & 0.011 & -0.161 & 43.516 & 0.000 \\
\hline 1 다 & 1 & 4 & 1 & 9 & -0.108 & -0.090 & 43.988 & 0.000 \\
\hline $1 \square$ & I & I & I & 10 & -0.191 & -0.045 & 45.598 & 0.000 \\
\hline $1 \square$ & 1 & 단 & 1 & 11 & -0.266 & -0.114 & 49.001 & 0.000 \\
\hline $1 \square$ & 1 & 1 & 1 & 12 & -0.320 & -0.048 & 54.416 & 0.000 \\
\hline
\end{tabular}

Figure 3 - Correlogram of R\&D (Portugal)

Additionally, unit root tests were conducted, in order to check whether the R\&D and GDP series are stationary or not. The results of the Augmented Dickey-Fuller (ADF) test expose the non stationarity of the series. For GDP the test fails to reject the null hypothesis of a unit root at any of the significance levels. Indeed, the ADF test Statistic (1.24) does not lie to the left of the MacKinnon (1996) critical values (-2.69 at 1\%, -1.96 at 5\%, and -1.61 at $10 \%$ ) (MacKinnon critical values are the ones for ADF testing in small samples). Therefore, the null hypothesis is accepted, and the GDP series has a unit root. In other words, it is non stationary.

Regarding the R\&D spending in Portugal, the test also fails to reject the null hypothesis of a unit root for the R\&D series. As a matter of fact, the ADF test Statistic (1.99) does not lie to the left of the MacKinnon critical values. For that reason, the null hypothesis is accepted and the $\mathrm{R} \& \mathrm{D}$ series is also non stationary.

The GDP and R\&D data for Portugal thus need to be transformed. In order to remove the trend component from the time series, we take first differences. The ADF Test Statistic (-2.27) for the GDP time series in first differences is now lesser than the 5\% MacKinnon critical value (-1.96), therefore the GDP time series for Portugal is integrated of order one. Even though it is close to the $10 \%$ level, the t-Statistic in the ADF test for the first difference of the R\&D time series (1.46) is above the MacKinnon critical value, pointing out the existence of a unit root. This result, however, appears to be influenced by the existence of outliers. Taken this into account and using Franses and Haldrup (1994), we would likely find that R\&D is indeed an I(1) series. In fact, if a dummy variable in the years 1993 to 1995 and 2002 to 2003 is included, then the first differences of the R\&D series visibly pass the $5 \%$ MacKinnon critical value: the $t$-Statistic $(-3.28)$ lies to the left of the respective $5 \%$ critical value $(-3.04)$. In order to further confirm that the R\&D series can be assumed as integrated of order one, the respective correlogram is analysed (Figure 4). As one can see, it does not show any signs of non-stationarity. Actually, the autocorrelation function lies within the error bands and dies off. 


\begin{tabular}{|c|c|c|c|c|c|c|c|c|}
\hline Autocorr & relation & Partial Co & lation & & $A C$ & PAC & Q-Stat & Prob \\
\hline 1 & $\square$ & 1 & & 1 & 0.458 & 0.458 & 5.0649 & 0.024 \\
\hline 1 & 日， & 요 & 1 & 2 & 0.136 & -0.094 & 5.5332 & 0.063 \\
\hline 1 둥 & ' & 10 & 1 & 3 & -0.153 & -0.227 & 6.1600 & 0.104 \\
\hline $1 \square$ & 1 & d & 1 & 4 & -0.232 & -0.077 & 7.6878 & 0.104 \\
\hline 1 무 & 1 & 1 & 1 & 5 & -0.145 & 0.036 & 8.3249 & 0.139 \\
\hline 1 & 1 & 1 & 1 & 6 & 0.030 & 0.097 & 8.3548 & 0.213 \\
\hline 1 & 1 & 1 & 1 & 7 & 0.060 & -0.064 & 8.4782 & 0.292 \\
\hline 1 & 与 & 1 & 1 & 8 & 0.099 & 0.042 & 8.8447 & 0.356 \\
\hline 1 & 1 & 1 & 1 & 9 & 0.069 & 0.030 & 9.0347 & 0.434 \\
\hline 1 & 巨 & 1 & 1 & 10 & 0.102 & 0.111 & 9.4919 & 0.486 \\
\hline 1 & ' & 1 & 1 & 11 & 0.032 & -0.044 & 9.5423 & 0.572 \\
\hline $1 \square$ & ' & $1 \square$ & 1 & 12 & -0.186 & -0.269 & 11,404 & 0.495 \\
\hline
\end{tabular}

Figure 4- First difference correlogram for Portuguese R\&D spending

As a conclusion, it is possible to confirm that both the GDP and R\&D series for Portugal, taken in natural logarithms, are I(1). Thus, we use the first-difference of the logarithms.

\section{Other countries}

The same testing procedures were applied to the GDP and R\&D series of Belgium, France, Germany, Ireland, Netherlands, Spain and the United Kingdom. These series do not prove to be I(0). After the first difference of logarithms is applied, however, the series became stationary. ${ }^{1}$ Under these conditions, it will be possible to proceed to co-integration testing. Following we present the results of the Augmented Dickey-Fuller test statistic for the first difference logarithm of these variables, as well as the respective correlograms.

\section{Belgium}

The t-Statistic values for Belgium, -4.44 and -3.49 respectively for GDP and R\&D, lie to the left of the MacKinnon critical values. Therefore, the null hypothesis can be rejected and the first differenced GDP and R\&D spending time series are stationary. The correlograms of the transformed series confirm the stationarity of the samples (Figure 5).

\section{(1) First Difference for GDP.}

Included observations: 21

\begin{tabular}{|c|c|c|c|c|c|c|c|c|}
\hline \multicolumn{2}{|c|}{ Autocorrelation } & \multicolumn{3}{|c|}{ Partial Correlation } & \multirow{2}{*}{$\frac{A C}{0.018}$} & \multirow{2}{*}{$\frac{\text { PAC }}{0.018}$} & \multirow{2}{*}{$\frac{\text { Q-Stat }}{0.0074}$} & \multirow{2}{*}{$\frac{\text { Prob }}{0.931}$} \\
\hline 1 & 1 & $\mathbf{1}$ & 1 & 1 & & & & \\
\hline 1 & 1 & 1 & 1 & 2 & 0.024 & 0.024 & 0.0226 & 0.989 \\
\hline 10 & 1 & 10 & 1 & 3 & $=0.085$ & -0.086 & 0.2148 & 0.975 \\
\hline & 1 & c & 1 & 4 & -0.408 & -0.409 & 4.9532 & 0.292 \\
\hline 10 & 1 & 1 近 & 1 & 5 & -0.092 & -0.105 & 5.2092 & 0.391 \\
\hline d & 1 & 1 d & 1 & 6 & -0.094 & -0.101 & 5.4938 & 0.482 \\
\hline 1 & 1 & 10 & 1 & 7 & -0.006 & -0.095 & 5.4948 & 0.600 \\
\hline 1 & 1 & $1 \square$ & 1 & 8 & -0.033 & -0.276 & 5.5346 & 0.699 \\
\hline 1 & 1 & 1 & 1 & 9 & 0.157 & 0.039 & 6.5256 & 0.686 \\
\hline 1 & 1 & 1 & 1 & 10 & 0.279 & 0.248 & 9.9527 & 0.445 \\
\hline 1 & 1 & 1 & 1 & 11 & $=0.031$ & $=0.113$ & 9.9995 & 0.530 \\
\hline 早 & 1 & 1 & 1 & 12 & 0.118 & -0.010 & 10.743 & 0.551 \\
\hline
\end{tabular}

(2) First Difference for R\&D.

\begin{tabular}{|c|c|c|c|c|c|c|c|c|}
\hline \multicolumn{2}{|c|}{ Autocorrelation } & \multicolumn{3}{|c|}{ Partial Correlation } & $A C$ & PAC & Q-Stat & Prob \\
\hline 1 & 1 & 1 & 1 & 1 & 0.189 & 0.189 & 0.8585 & 0.354 \\
\hline 1 & । & 1 & 1 & 2 & -0.001 & -0.038 & 0.8586 & 0.651 \\
\hline 1 ㅁ & 1 & $1 \square$ & 1 & 3 & -0.201 & -0.201 & 1.9414 & 0.585 \\
\hline 1 & 1 & 1 & 1 & 4 & -0.056 & 0.021 & 2.0303 & 0.730 \\
\hline 1 & 1 & 1 & 1 & 5 & -0.098 & -0.098 & 2.3180 & 0.804 \\
\hline $1 \square$ & 1 & 10 & 1 & 6 & -0.283 & $=0.315$ & 4.9004 & 0.557 \\
\hline 1 & I & ， 日 & 1 & 7 & 0.015 & 0.136 & 4.9082 & 0.671 \\
\hline 1 & 1 & 马 & 1 & 8 & $=0.025$ & $=0.105$ & 4.9322 & 0.765 \\
\hline 1 & 1 & 4 & 1 & 9 & 0.035 & -0.102 & 4.9801 & 0.836 \\
\hline $1 \square$ & 1 & 단 & 1 & 10 & $=0.340$ & $=0.377$ & 10.045 & 0.437 \\
\hline 10 & 1 & 1 & 1 & 11 & -0.083 & -0.043 & 10.379 & 0.497 \\
\hline 1 & 1 & 1 d & 1 & 12 & 0.015 & $=0.115$ & 10.390 & 0.582 \\
\hline
\end{tabular}

Figure 5- First difference correlograms for GDP and R\&D - Belgium

${ }^{1}$ However, it should be mentioned that these results were not obvious in the first place for some countries, such as Spain. The main reasons for these problems are related to outliers and to the size of the sample. 


\section{France}

The t-Statistic values for France, -2.05 and -2.57 respectively for GDP and R\&D, lie to the left of the MacKinnon critical values. The null hypothesis can be rejected and the first differenced GDP and R\&D spending time series are stationary. The correlograms of the transformed series confirm the stationarity of the samples (Figure 6).

(1) First Difference for GDP.

Included observations: 21

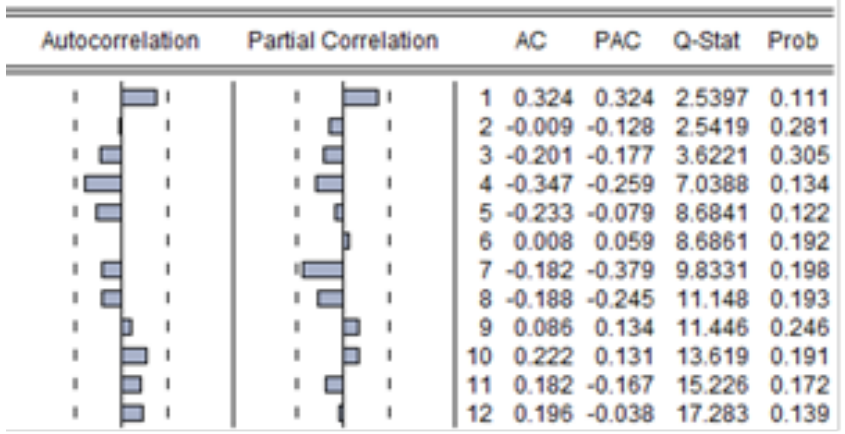

(2) First Difference for R\&D.

Included observations: 21

\begin{tabular}{|c|c|c|c|c|c|c|c|c|}
\hline \multicolumn{2}{|c|}{ Autocorrelation } & \multicolumn{3}{|c|}{ Partial Correlation } & \multirow{2}{*}{$\frac{A C}{0.304}$} & \multirow{2}{*}{$\frac{\text { PAC }}{20.304}$} & \multirow{2}{*}{$\frac{\text { Q-Stat }}{2.2335}$} & \multirow{2}{*}{$\begin{array}{c}\text { Prob } \\
0.135\end{array}$} \\
\hline 1 & $\square^{\prime}$ & $\boxminus$ & & 1 & & & & \\
\hline 1 & : & $1 \quad \square$ & 1 & 2 & 0.309 & 0.239 & 4.6645 & 0.097 \\
\hline 1 & I & $1 \square$ & 1 & 3 & -0.045 & -0.222 & 4.7200 & 0.193 \\
\hline $1 \square$ & 1 & $\square$ & 1 & 4 & -0.352 & -0.444 & 8.2448 & 0.083 \\
\hline 1 둥 & ' & b & 1 & 5 & -0.162 & 0.133 & 9.0418 & 0.107 \\
\hline$\square$ & ' & 10 & 1 & 6 & -0.368 & -0.121 & 13.391 & 0.037 \\
\hline 15 & 1 & ' & 1 & 7 & -0.101 & -0.056 & 13.740 & 0.056 \\
\hline 1 & ' & ' & 1 & 8 & -0.063 & -0.030 & 13.886 & 0.085 \\
\hline 1 & b 1 & b & 1 & 9 & 0.080 & 0.122 & 14.144 & 0.117 \\
\hline 1 & $\boxminus$ i & 巨 & 1 & 10 & 0.281 & 0.140 & 17.605 & 0.062 \\
\hline 1 & 巨。 & ' & 1 & 11 & 0.174 & -0.012 & 19.073 & 0.060 \\
\hline 1 & 巨 1 & d & 1 & 12 & 0.171 & -0.114 & 20.647 & 0.056 \\
\hline
\end{tabular}

\section{Germany}

Figure 6- First difference correlograms for GDP and R\&D - France

The t-Statistics for Germany, -1.77 and -1.94 respectively for GDP and R\&D, do not lie to the left of the 5\% MacKinnon critical value but are really close to it (in the case of R\&D) and pass the $10 \%$ critical value. As with the R\&D spending stationarity tests for Portugal, an analysis on the first difference graph and correlogram is needed in order to conclude that both the GDP and R\&D spending series are integrated of order one (Figure 7). As the results show, they both seem to prove stationarity. In conclusion, the two series are I(1) and the fact that they appeared to be integrated of order two was likely related to the size of the sample and to outliers.

(1) First Difference for GDP.

Included observations: 21

\begin{tabular}{|c|c|c|c|c|c|c|c|c|}
\hline \multicolumn{2}{|c|}{ Autocorrelation } & \multicolumn{3}{|c|}{ Partial Correlation } & \multirow{2}{*}{$\begin{array}{l}A C \\
0.456\end{array}$} & \multirow{2}{*}{$\begin{array}{l}\text { PAC } \\
0.456\end{array}$} & \multirow{2}{*}{$\begin{array}{l}\text { Q-Stat } \\
5.0265\end{array}$} & \multirow{2}{*}{$\begin{array}{l}\text { Prob } \\
0.025\end{array}$} \\
\hline 1 & 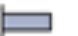 & I & & 1 & & & & \\
\hline , & bi & & 1 & 2 & 0.068 & -0.177 & 5.1433 & 0.076 \\
\hline 1 & ' & ' & 1 & & -0.008 & 0.047 & 5.1. & 0.161 \\
\hline $1 \mathrm{~d}$ & ' & 듬 & 1 & & -0.130 & -0.174 & 5.6259 & 0.228 \\
\hline c & ' & 1 & 1 & & -0.138 & 0.002 & 6.2032 & 0.287 \\
\hline 1 & ' & ' & 1 & 6 & 0.0 & & & 0.384 \\
\hline 1 & ' & 듬 & 1 & & -0.045 & -0.237 & 6.4324 & 0.490 \\
\hline I & ' & 1 口 & 1 & & -0.015 & 0.166 & 6.4405 & 0.598 \\
\hline i & b & , & 1 & 9 & 0.165 & 0.108 & & 0.582 \\
\hline 18 & 5 , & ' & 1 & 10 & 0.106 & -0.041 & 8.0227 & 0.627 \\
\hline 15 & I & 1 ㅁ & 1 & 11 & -0.117 & & 8.6833 & 0.651 \\
\hline 1 ב & ' & 10 & 1 & 12 & -0.146 & -0.068 & 9.8204 & 0.632 \\
\hline
\end{tabular}

(2) First Difference for R\&D.

\begin{tabular}{l} 
Included observations: 21 \\
\hline \hline Autocorrelation \\
\hline \hline
\end{tabular}

Figure 7- First difference correlograms for GDP and R\&D - Germany

\section{Ireland}

The t-Statistic value for the R\&D time series, -2.01 , lies to the left of the $5 \%$ MacKinnon critical value. Therefore, the assumption of the series as being stationary is acceptable. As-regards the GDP series, the t-Statistic $(-2.84)$ fails to pass the $5 \%$ critical level but clearly passes the $10 \%$ level. Still, correlogram analysis is conducted in order to confirm that both the GDP and R\&D series are integrated of order one (Figure 8). 


\section{(1) First Difference for GDP.}

Included observations: 20

\begin{tabular}{|c|c|c|c|c|c|c|c|c|}
\hline \multicolumn{2}{|c|}{ Autocorrelation } & \multicolumn{3}{|c|}{ Partial Correlation } & \multirow{2}{*}{$\frac{A C}{0.501}$} & \multirow{2}{*}{$\frac{P A C}{0.501}$} & \multirow{2}{*}{$\frac{\text { Q-Stat }}{5.8115}$} & \multirow{2}{*}{$\frac{\text { Prob }}{0.016}$} \\
\hline 1 & $\square$ & ' & & 1 & & & & \\
\hline 1 & יש & 1 & 1 & 2 & 0.369 & 0.158 & 9.1392 & 0.010 \\
\hline 1 & 1 & ' 든 & 1 & 3 & 0.078 & -0.214 & 9.2969 & 0.026 \\
\hline 1 물 & 1 & & I & 4 & -0.245 & -0.379 & 10.944 & 0,027 \\
\hline 1 므 & 1 & 1 & 1 & 5 & -0.195 & 0.126 & 12.059 & 0.034 \\
\hline & 1 & 1 & 1 & 6 & -0.501 & -0.397 & 19.950 & 0.003 \\
\hline$\square$ & 1 & I & 1 & 7 & -0.381 & -0.053 & 24.876 & 0.001 \\
\hline $1 \square$ & 1 & ' & 1 & 8 & -0.350 & -0.078 & 29.355 & 0.000 \\
\hline $1 \mathrm{G}$ & 1 & ' & 1 & 9 & -0.180 & 0.138 & 30.647 & 0.000 \\
\hline 1 & 1 & t & 1 & 10 & 0.047 & -0.099 & 30.744 & 0.001 \\
\hline 1 & 1 & $1 \mathrm{~g}$ & 1 & 11 & -0.003 & -0.163 & 30.744 & 0.001 \\
\hline 1 & 1 & 1 무 & 1 & 12 & 0.091 & -0.202 & 31.195 & 0.002 \\
\hline
\end{tabular}

(2) First Difference for R\&D.

Included observations: 21

\begin{tabular}{|c|c|c|c|c|c|c|c|c|}
\hline \multicolumn{2}{|c|}{ Autocorrelation } & \multicolumn{2}{|c|}{ Partial Correlation } & & $A C$ & PAC & Q-Stat & Prob \\
\hline 1 & & 1 & & 1 & 0.768 & 0.768 & 14.234 & 0.000 \\
\hline 1 & $\square$ & & 1 & 2 & 0.559 & -0.073 & 22.186 & 0.000 \\
\hline 1 & & 1 도 & 1 & 3 & 0.329 & -0.186 & 25.086 & 0.000 \\
\hline 1 & 1 & 11 & 1 & 4 & 0.151 & -0.045 & 25.732 & 0.000 \\
\hline 1 & 1 & 1 ㄷ & I & 5 & $=0.029$ & -0.151 & 25.757 & 0.000 \\
\hline 19 & 1 & 1 & 1 & 6 & -0.126 & 0.014 & 26.272 & 0.000 \\
\hline 1 뭉 & 1 & 1 무 & 1 & 7 & -0.255 & -0.200 & 28.510 & 0.000 \\
\hline 10 & 1 & 1 & 1 & 8 & -0.325 & -0.063 & 32.446 & 0.000 \\
\hline$\square$ & 1 & 1 & 1 & 9 & -0.362 & -0.033 & 37.706 & 0.000 \\
\hline 듬 & 1 & 1 & 1 & 10 & -0.321 & 0.035 & 42.228 & 0.000 \\
\hline $1 \square$ & 1 & 1 & 1 & 11 & -0.263 & 0.003 & 45.566 & 0.000 \\
\hline 1 口 & 1 & 1 & 1 & 12 & -0.134 & 0.105 & 46.528 & 0.000 \\
\hline
\end{tabular}

Figure 8- First difference correlograms for GDP and R\&D - Ireland

\section{Netherlands}

The t-Statistics for Netherlands, -3.20 and -3.28 respectively for GDP and R\&D, lie to the left of the MacKinnon critical values. Therefore, the null hypothesis can be rejected and the first differenced GDP and R\&D spending time series are stationary. The correlograms of the transformed series confirm the stationarity of the first differences (Figure 9).

(1) First Difference for GDP.

Included observations: 21

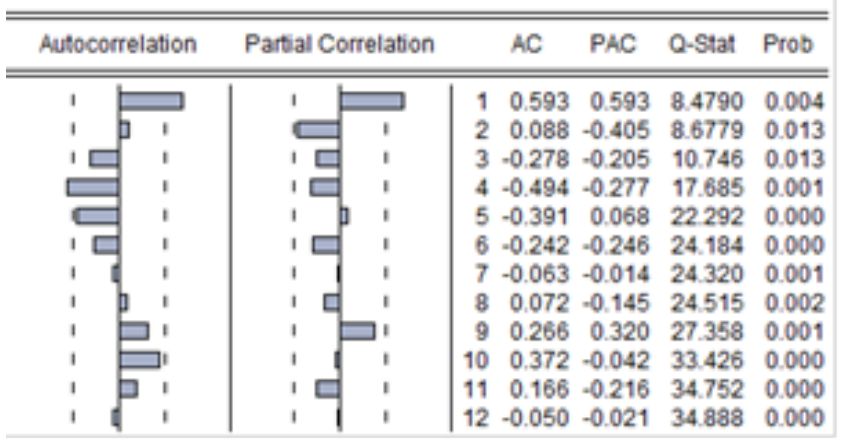

(2) First Difference for R\&D.

\begin{tabular}{|c|c|c|c|c|c|c|c|c|}
\hline \multicolumn{2}{|c|}{ Autocorrelation } & \multicolumn{3}{|c|}{ Partial Correlation } & \multirow{2}{*}{$\begin{array}{l}\text { AC } \\
0.216\end{array}$} & \multirow{2}{*}{$\begin{array}{l}\text { PAC } \\
0.216\end{array}$} & \multirow{2}{*}{$\begin{array}{l}\text { Q-Stat } \\
1.1229\end{array}$} & \multirow{2}{*}{$\begin{array}{c}\text { Prob } \\
0.289\end{array}$} \\
\hline 1 & 1 & 曰 & 1 & 1 & & & & \\
\hline & 1 & 1 & 1 & 2 & 0.188 & 0.149 & 2.0224 & 0.364 \\
\hline $1 \sqsubset$ & 1 & $1 \square$ & 1 & 3 & -0.194 & -0.280 & 3.0333 & 0.387 \\
\hline 10 & 1 & 10 & 1 & 4 & -0.133 & -0.077 & 3.5335 & 0.473 \\
\hline 1 & 1 & 1 & 1 & 5 & -0.095 & 0.047 & 3.8042 & 0.578 \\
\hline 1 & 1 & $1 \square$ & 1 & 6 & -0.256 & -0.296 & 5.9103 & 0.433 \\
\hline & 1 & 1 & 1 & 7 & -0.088 & -0.025 & 6.1761 & 0.519 \\
\hline 口 & 1 & 16 & 1 & 8 & -0.370 & -0.327 & 11.263 & 0.187 \\
\hline 1 & 1 & 1 & 1 & 9 & 0.011 & 0.045 & 11.268 & 0.258 \\
\hline I & 1 & p & 1 & 10 & 0.062 & 0.139 & 11.437 & 0.324 \\
\hline 1 & 1 & d & 1 & 11 & 0.178 & -0.092 & 12.970 & 0.295 \\
\hline 1 & 1 & 10 & 1 & 12 & 0.065 & -0.123 & 13.197 & 0.355 \\
\hline
\end{tabular}

\section{Spain}

Figure 9- First difference correlograms for GDP and R\&D - Netherlands

The t-Statistic value for the R\&D series $(-2.75)$ lies to the left of the $1 \%$ MacKinnon critical value, suggesting stationarity in first differences. On the other hand, the GDP series does not pass the ADF test (t-Statisitc of -1.45) but is very close to the $10 \%$ critical level. This happens probably because of the existence of a punctual break (outlier) in 1993. If this punctual break is taken into account, relying on Franses and Haldrup (1994) results the GDP series visibly passes the $5 \%$ MacKinnon critical value. The t-Statistic $(-3.61)$ now lies to the left of the respective $5 \%$ critical value $(-3.04)$.

A correlogram is convenient in order to assure that GDP, besides R\&D, is integrated of order one. As the results suggest, the correlogram seems to prove the stationarity of the sample (Figure 10). 
(1) First Difference for GDP.

Included observations: 21

\begin{tabular}{|c|c|c|c|c|c|c|c|c|}
\hline \multicolumn{2}{|c|}{ Autocorrelation } & \multicolumn{2}{|c|}{ Partial Correlation } & & $A C$ & PAC & Q-Stat & Prob \\
\hline $\mathrm{I}$ & 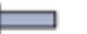 & I & $\sqsupset$ & 1 & 0.526 & 0.526 & 6.6712 & 0.010 \\
\hline 1 & ( 1 & 1 口 & 1 & 2 & 0.125 & -0.210 & 7.0654 & 0.029 \\
\hline 1 C & 1 & $1 \mathrm{C}$ & 1 & 3 & -0.113 & -0.119 & 7.4094 & 0.060 \\
\hline $1 \square$ & 1 & 10 & 1 & 4 & -0.353 & -0.300 & 10.950 & 0.027 \\
\hline & 1 & 1 & 1 & 5 & -0.378 & -0.073 & 15.268 & 0,009 \\
\hline 1 ㅁ & 1 & , & 1 & 6 & -0.220 & 0.008 & 16.834 & 0.010 \\
\hline 명 & 1 & 든 & 1 & 7 & -0.264 & -0.342 & 19.244 & 0.007 \\
\hline 1 且 & 1 & 1 & 1 & 8 & -0.185 & -0.072 & 20.518 & 0.009 \\
\hline 1 & 1 & , & 1 & 9 & 0.028 & 0.036 & 20.550 & 0.015 \\
\hline 1 & 1 & d & 1 & 10 & 0.077 & -0.116 & 20.809 & 0.022 \\
\hline 1 & 1 & 1 口 & 1 & 11 & 0.079 & -0.143 & 21.114 & 0.032 \\
\hline 1 & 1 & 1 무 & 1 & 12 & 0.061 & -0.189 & 21.314 & 0.046 \\
\hline
\end{tabular}

(2) First Difference for R\&D.

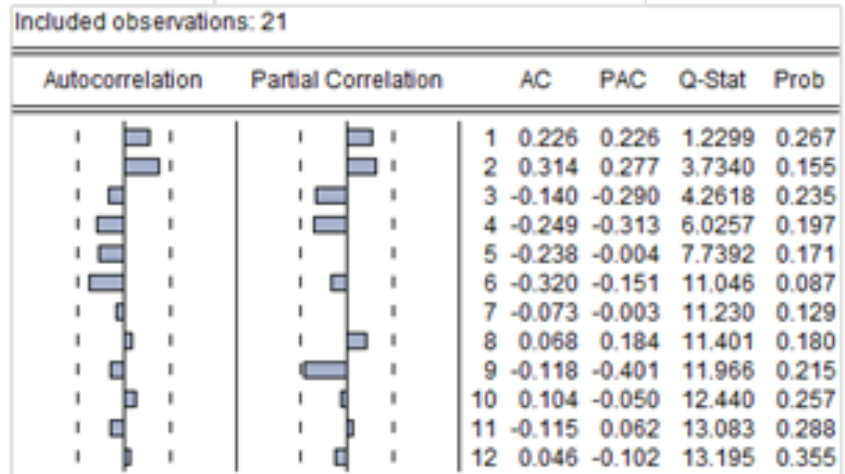

Figure 10- First difference correlograms for GDP and R\&D - Spain

\section{United Kingdom}

The t-Statistic value for R\&D (-3.47) lies to the left of the MacKinnon critical values. Regarding the GDP series, the $10 \%$ level is passed and the $5 \%$ critical value is almost reached as well $(\mathrm{t}-$ Statistic equal to -1.84). Therefore, the null hypothesis can be rejected. The first differenced GDP and R\&D spending time series are stationary. The correlograms of the transformed series confirm the stationarity of the samples (Figure 11).

(1) First Difference for GDP.

Included observations: 21

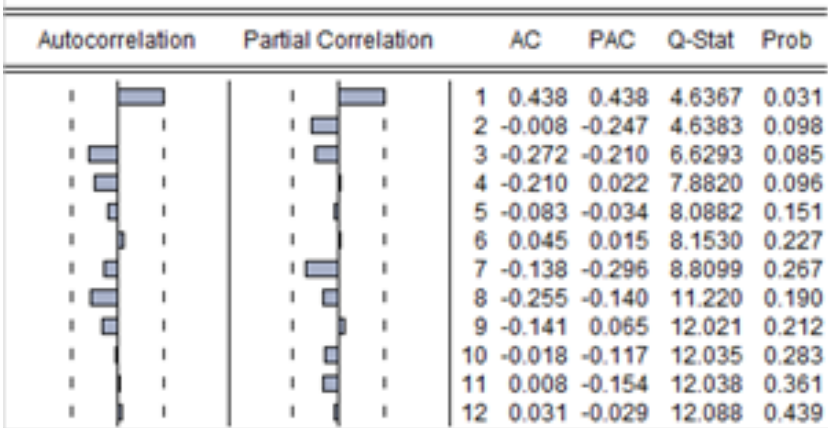

(2) First Difference for R\&D.

\begin{tabular}{|c|c|c|c|c|c|c|c|c|}
\hline \multicolumn{2}{|c|}{ Autocorrelation } & \multicolumn{2}{|c|}{ Partial Correlation } & \multirow{2}{*}{\multicolumn{2}{|c|}{$\begin{array}{cc}A C \\
1 \quad 0.151\end{array}$}} & \multirow{2}{*}{$\begin{array}{l}\text { PAC } \\
0.151\end{array}$} & \multirow{2}{*}{$\frac{\text { Q-Stat }}{0.5503}$} & \multirow{2}{*}{$\begin{array}{l}\text { Prob } \\
0.458\end{array}$} \\
\hline ' & 1 & 1 & 1 & & & & & \\
\hline $1 \square$ & 1 & $\square$ & 1 & 2 & -0.264 & -0.293 & 2.3198 & 0.314 \\
\hline 1 문 & 1 & 1 且 & 1 & 3 & -0.245 & -0.168 & 3.9361 & 0.268 \\
\hline 10 & 1 & 10 & 1 & 4 & -0.074 & -0.093 & 4.0898 & 0.394 \\
\hline ' & 1 & ' & 1 & 5 & -0.012 & -0.115 & 4.0942 & 0.536 \\
\hline ' & 1 & I & 1 & 6 & 0.148 & 0.092 & 4.8013 & 0.570 \\
\hline ' & 1 & 당 & 1 & 7 & -0.015 & -0.131 & 4.8090 & 0.683 \\
\hline 1 & 1 & ' & 1 & 8 & -0.104 & -0.066 & 5.2084 & 0.735 \\
\hline 1 & 1 & ' & 1 & 9 & -0.018 & 0.005 & 5.2221 & 0.815 \\
\hline ' & 1 & 15 & 1 & 10 & -0.053 & -0.142 & 5.3459 & 0.867 \\
\hline I & 1 & 1 & I & 11 & $=0.042$ & $=0.052$ & 5.4309 & 0.909 \\
\hline 日 & 1 & 1 & 1 & 12 & 0.129 & 0.070 & 6.3190 & 0.899 \\
\hline
\end{tabular}

Figure 11- First difference correlograms for GDP and R\&D - United Kingdom

\section{Co-integration Testing \\ Portugal}

A linear combination of two or more non-stationary series may be stationary. If such a linear combination exists, the non-stationary time series are said to be co-integrated. The stationary linear combination is called the co-integrating equation and can be interpreted as a long-run equilibrium relationship between the variables (Engle and Granger, 1987).

In order to prove whether there is a long-term equilibrium relationship between GDP and R\&D spending, the co-integration test can be performed by using the Johansen method, by looking at the eigenvalue statistic. The Johansen's multivariate co-integration test consists of analyzing the relationships between the GDP and R\&D variables by using a vector auto-regression (VAR) model. Before performing this test, it is important to verify that residuals are normal, since the maximum likelihood existent in the Johansen co-integration test assumes that the residuals are distributed as in a Normal distribution. The Doornik-Hansen (2008) test is suitable to jointly 
test for residuals' normality and was employed. We selected a VECM(1) with a standard information criteria. Figure 12 shows the results for Portugal.

\section{VEC Residual Normality Tests}

[Orthogonalization: Residual Correlation (Doornik-Hansen)]

[Null Hypothesis: residuals are multivariate normal]

[Sample: 1987 2008] [Included observations: 18]

\begin{tabular}{|c|c|c|c|c|}
\hline Component & Skewness & Chi-sq & df & Prob. \\
\hline 1 & -0.909734 & 3.399947 & 1 & 0.0652 \\
\hline 2 & 0.483463 & 1.051243 & 1 & 0.3052 \\
\hline Joint & & 4.451190 & 2 & 0.1080 \\
\hline Component & Kurtosis & Chi-sq & $\mathrm{df}$ & Prob. \\
\hline 1 & 3.217576 & 0.212653 & 1 & 0.6447 \\
\hline 2 & 3.437186 & 1.834621 & 1 & 0.1756 \\
\hline Joint & & 2.047273 & 2 & 0.3593 \\
\hline Component & Jarque-Bera & $\mathrm{df}$ & Prob. & \\
\hline 1 & 3.612599 & 2 & 0.1643 & \\
\hline 2 & 2.885863 & 2 & 0.2362 & \\
\hline Joint & 6.498463 & 4 & 0.1649 & \\
\hline
\end{tabular}

Figure 12 - Doornik-Hansen residual normality test (Portugal)

Given these results, it is possible to confirm that the null hypothesis cannot be rejected and that the residuals are multivariate normal. Consequently, the Johansen co-integration test can be performed. The results are shown in Figure 13. As the Max-Eigen Statistic value (10.59934) is lower than the 0.05 critical value, the existence of co-integration is rejected. In other terms, the Johansen's method cannot confirm that there is any co-integration vector. Therefore, for the case of Portugal, it is not possible to conclude that there is a stable long-run relationship between GDP and R\&D.

\begin{tabular}{|c|c|c|c|c|}
\hline $\begin{array}{r}\text { Incl } \\
\text { Tren } \\
\mathrm{La}\end{array}$ & $\begin{array}{l}\text { Sample (ad } \\
\text { ded observat } \\
\text { assumption: } \\
\text { Series: LNGD } \\
\text { s interval (in }\end{array}$ & $\begin{array}{l}\text { sted): } 1989 \\
\text { ns: } 20 \text { after a } \\
\text { inear determ } \\
\text { P001 LNRD } \\
\text { rst differenc }\end{array}$ & $\begin{array}{l}08 \\
\text { ustments } \\
\text { istic trend } \\
001 \\
\text { : } 1 \text { to } 1\end{array}$ & \\
\hline Unrestricted Co & ntegration $\mathrm{F}$ & nk Test (Ma & mum Eiger & ralue) \\
\hline Hypothesized & & Max-Eigen & 0.05 & \\
\hline No. of CE(s) & Eigenvalue & Statistic & $\begin{array}{c}\text { Critical } \\
\text { Value }\end{array}$ & Prob.** \\
\hline None & 0.411376 & 10.59934 & 14.26460 & 0.1755 \\
\hline At most 1 & 0.009977 & 0.200544 & 3.841466 & 0.6543 \\
\hline $\begin{array}{l}\text { Max-eigenvalue } \\
* \text { denotes rejectior } \\
* * \text { MacKinnon-Hau }\end{array}$ & $\begin{array}{l}\text { indicates no } \\
\text { the hypothesi } \\
\text { ichelis (1999) }\end{array}$ & $\begin{array}{l}\text { tegration at } \\
\text { the } 0.05 \text { level } \\
\text { alues }\end{array}$ & 0.05 level & \\
\hline
\end{tabular}

Figure 13 - Johansen co-integration test for GDP and R\&D spending (Portugal)

\section{Other countries}

The same analysis was performed for the other countries - Belgium, France, Germany, Ireland, Netherlands, Spain and the United Kingdom. A co-integration vector linking GDP and R\&D spending was found only for the case of the United Kingdom, but with the unexpected sign 
(negative relationship, instead of positive) ${ }^{2}$ Concluding, no co-integration was found between GDP and R\&D spending for any of the EU countries considered.

This subsection presents the results for the Doornik-Hansen residual normality test, the Johansen co-integration test and the respective Vector Error Correction Model (VECM), whenever applicable. We selected a VECM(1) with a standard information criteria.

\section{Belgium}

Given the 0.0032 p-value in the Doornik-Hansen test, residual normality fails. However, one can see that only the residual for one of the equations fails to meet kurtosis. Having this in mind, we still take the Johansen procedure. As the Max-Eigen Statistic value (5.60) is lower than the $5 \%$ critical value (14.26), the existence of co-integration is rejected. Therefore it is not possible to conclude that there exists a stable long run relationship between GDP and R\&D.

\section{France}

Given the $0.4946 \mathrm{p}$-value in the Doornik-Hansen residual normality test, it is confirmed that the residuals follow a Normal distribution, and therefore the Johansen procedure for testing for co-integration is valid. As the Max-Eigen Statistic value (14.14) is lower than the $5 \%$ critical value (14.26), co-integration is rejected. Therefore it is not possible to conclude that there is a stable long run relationship between GDP and R\&D.

\section{Germany}

Given the 0.7835 p-value in the Doornik-Hansen residual normality test, it is confirmed that the residuals follow a Normal distribution. Consequently, the Johansen procedure for testing for co-integration is valid. As the Max-Eigen Statistic value (12.57) is lower than the 5\% critical value (14.26), the existence of co-integration is rejected. Therefore it is not possible to conclude that there is a stable long run relationship between GDP and R\&D.

\section{Ireland}

Given the 0.7420 p-value in the Doornik-Hansen residual normality test, it is confirmed that the residuals follow a Normal distribution. Therefore, the Johansen procedure for testing for co-integration is valid. The results of the Johansen test indicate that there are two cointegrating vectors describing this model. This odd result (at most one would be expected) may actually be a symptom of the possible existence of structural breaks, either in the joint behaviour of GDP and R\&D or, somewhat, in each of these.

\section{Netherlands}

Given the 0.6239 p-value in the Doornik-Hansen residual normality test, it is confirmed that the residuals follow a Normal distribution. As a result, the Johansen procedure for testing for co-integration is valid. As the Max-Eigen Statistic value (13.34) is lower than the 5\% critical value (14.26), the existence of co-integration is rejected. Therefore it is not possible to conclude that there is a stable long run relationship between GDP and R\&D.

\footnotetext{
2 Recall that, following Engle and Granger (1987), a system of co-integrated variables can be characterized by a dynamic error correction model (ECM), so accordingly a Vector ECM (VECM) was estimated by JohansenJuselius (1990) method for UK data. However, a surprising negative long-run relationship between R\&D and GDP was obtained. This result may stem from the existence of structural breaks, either in the joint behaviour of GDP and R\&D or in each of these.
} 


\section{Spain}

Given the $0.7652 \mathrm{p}$-value in the Doornik-Hansen residual normality test, it is confirmed that the residuals follow a Normal distribution, and therefore the Johansen procedure for testing for co-integration is valid. As the Max-Eigen Statistic value (9.95) is lower than the $5 \%$ critical value (14.26) the existence of co-integration is rejected. Therefore it is not possible to conclude that there is a stable long run relationship between GDP and R\&D.

\section{United Kingdom}

Given the $0.8165 \mathrm{p}$-value in the Doornik-Hansen residual normality test, it is confirmed that the residuals follow a Normal distribution. Consequently, the Johansen procedure for testing for co-integration is valid. The results of the Johansen test indicate that there is a co-integrating vector describing this model. The Maximum Eigenvalue statistic (19.86) is higher than the respective $5 \%$ critical value (14.26). This suggests that there is a stable long run relationship between the GDP and R\&D spending variables for the case of the United Kingdom.

Following Engle and Granger (1987), a system of co-integrated variables can be characterized by a dynamic error correction model (ECM). Accordingly, a Vector ECM (VECM) is estimated by Johansen-Juselius (1990) method. The results are presented below (Figure 14). 
Vector Error Correction Estimates

Sample (adjusted): 19902008

Included observations: 19 after adjustments

Standard errors in ( ) \& t-statistics in [ ]

Cointegrating Eq: CointEq1

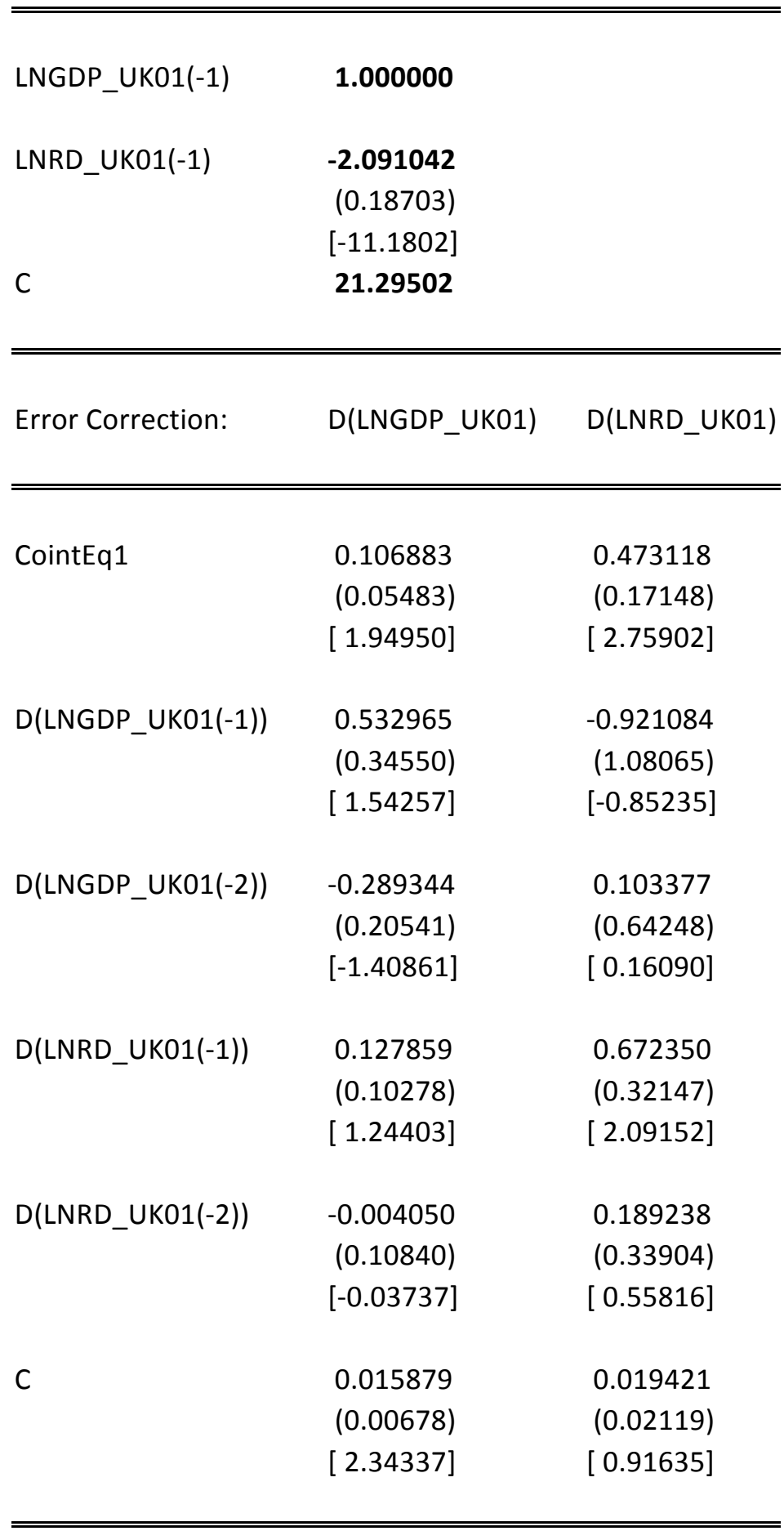

Figure 14 - Vector Error Correction Estimates - United Kingdom 
The surprising negative long-run relationship between R\&D and GDP may stem from the existence of structural breaks, either in the joint behaviour of GDP and R\&D or in each of these.

\section{Granger Causality Testing Portugal}

Granger causality is a circumstance in which one time series variable helps to predict the other one. The importance of the Granger causality test comes from the fact that it makes possible to analyse which variable precedes another one. This can be particularly convenient for forecasting purposes. As stated by Granger (1988), if there is a co-integrating vector between R\&D expenditure and GDP, there is causality among those variables at least in one direction. Granger causality tests can be used to examine the nature of this relationship. When there is no co-integration between the variables, causality may still exist.

Given the absence of co-integration between R\&D spending and GDP, the causality test is performed in the VAR in first differences. This can also be interpreted in terms of testing causality between GDP growth and R\&D growth. Figure 15 displays the results for Portugal.

Pairwise Granger Causality Tests

Sample: 19872008

Lags: 1

\begin{tabular}{lccr}
\hline \hline Null Hypothesis: & Obs & F-Statistic & Prob. \\
\hline \hline DLN_RD_PO does not Granger Cause DLN_GDP_PO & 20 & 0.44547 & 0.5135 \\
DLN_GDP_PO does not Granger Cause DLN_RD_PO & & 0.35154 & 0.5610 \\
\hline \hline
\end{tabular}

Figure 15 - Pairwise Granger Causality Tests for GDP and R\&D (Portugal)

The outcome of the test is not enough to reject the null hypothesis that R\&D growth does not Granger cause GDP growth and vice-versa. However, it should be mentioned that, despite this, the causal relationship is more likely to run from R\&D to GDP than the other way round. Actually, the probability that GDP growth does not Granger cause R\&D growth is higher than in the opposite case.

\section{Other countries}

As for the other countries being analysed, Granger causality could be proven for France, the Netherlands and Spain. As a matter of fact, the outcomes of the tests reveal a unidirectional causal link running from GDP to R\&D investment for France and Spain, in terms of these variables growth. In addition, a unidirectional causal link running from R\&D investment to GDP growth is found for the case of the Netherlands. For the rest of the EU countries analyzed, the probabilities are not low enough so that it is possible to reject the null hypothesis of no Granger causality with a robust confidence level. This means that for Belgium, Germany, Ireland and the United Kingdom there is no causal relationship between GDP growth and R\&D growth that could be proven.

The results of the Granger Causality test performed on the first difference (logarithm) of the GDP and R\&D spending time series for Belgium, France, Germany, Ireland, Netherlands, Spain and the United Kingdom are presented below (Table 1). 
Table 1 - Pairwise Granger Causality Tests

Sample: 1987 2008. Obs: 20, Lags: 1

\begin{tabular}{|c|c|c|c|c|c|c|c|}
\hline & Belgium & France & Germany & Ireland & Netherlands & Spain & UK \\
\hline $\begin{array}{c}\text { DLNRD does not } \\
\text { Granger Cause } \\
\text { DLNGDP }\end{array}$ & & & & & & & \\
F-Statistic & 0.70014 & 1.33480 & 0.12436 & 0.22870 & 3.57768 & 0.06312 & 0.00186 \\
Prob. & 0.4143 & 0.2639 & 0.12436 & 0.6386 & 0.0757 & 0.8046 & 0.9661 \\
\hline $\begin{array}{c}\text { DLNGDP does not } \\
\text { Granger Cause } \\
\text { DLNRD }\end{array}$ & & & & & & & \\
F-Statistic & 0.00137 & 9.79243 & 1.12904 & 1.30825 & 2.28000 & 16.6038 & 0.99576 \\
Prob. & 0.9709 & 0.0061 & 0.3028 & 0.2686 & 0.1494 & 0.0008 & 0.3323 \\
\hline
\end{tabular}

\section{SUMMARY OF RESULTS AND DISCUSSION}

This paper investigates the causal relationship linking R\&D investment and economic growth in a sample of EU countries. We show that the causal link between R\&D growth and GDP growth may exist, but it does not affect all countries in the same way. Despite the strong effort that Portugal did in order to comply with the EU2020 R\&D target of 3\%, the co-integration and Granger causality tests failed to prove that increased R\&D investment engenders increased economic growth and/or vice-versa. However, for other countries such as France and Spain, a Granger causal relationship running from GDP growth to R\&D growth could be proven. For the Netherlands, a unidirectional causal link running from R\&D investment to GDP growth was found.

Table 2 summarizes our empirical findings.

Table 2 - Main empirical findings

\begin{tabular}{|l|c|c|c|}
\hline \multirow{2}{*}{ Country } & \multirow{2}{*}{ Co-integration test } & \multicolumn{2}{|c|}{ Granger Causality Test } \\
\cline { 3 - 4 } & & GDP to R\&D & R\&D to GDP \\
\hline Portugal & $\mathbf{X}$ & $\mathbf{X}$ & $\mathbf{X}$ \\
\hline Belgium & $\mathbf{X}$ & $\mathbf{X}$ & $\mathbf{X}$ \\
\hline France & $\mathbf{X}$ & $\mathbf{V}$ & $\mathbf{X}$ \\
\hline Germany & $\mathbf{X}$ & $\mathbf{X}$ & $\mathbf{X}$ \\
\hline Ireland & $\mathbf{X}$ & $\mathbf{X}$ & $\mathbf{X}$ \\
\hline Netherlands & $\mathbf{X}$ & $\mathbf{X}$ & $\mathbf{V}$ \\
\hline Spain & $\mathbf{X}$ & $\mathbf{V}$ & $\mathbf{X}$ \\
\hline United Kingdom & $\mathbf{V}$ & $\mathbf{X}$ & $\mathbf{X}$ \\
\hline
\end{tabular}

The fact that a co-integrating vector linking GDP and R\&D could not be found for the majority of the countries analysed, questions the usually presumed existence of a long-run relationship between these variables. The results obtained do not indicate that expenditures in $R \& D$ are directly related with economic growth. Actually, the amount of money invested in R\&D does not seem to be sufficient to stimulate economic growth. The way in which money is invested also accounts for the final outcome and might explain why some countries can reap the benefits of such investment better than others. This is especially valid for countries like Portugal, where R\&D investment has increased at a fast pace but the economic returns were unseen. Possibly, only measures of actual innovation, fuelling total factor productivity, do bear 
a significant link with economic growth. Another important issue to address is the role of public versus private R\&D investment. The data employed in this study does not separate the two. However, an interesting advance would be to analyse whether a long-run relationship and/or a causality relationship exist between economic growth and one of these variables. This is left for future work.

Taking our results into account, a conclusion that can be drawn is that substantial reforms should be undertaken in the countries where a causal relationship could not be verified, as is the case of Portugal. This comes in line with other papers such as Tavares (2004) and Teixeira (2007), which also concluded that Portuguese science and technology institutions need to be reformed in order to maximize the benefits of R\&D investment. Given that different R\&D policies may have considerably dissimilar impacts on each EU economy, EU states should focus more on the effectiveness of their R\&D policies rather than on simply meeting the EU goals for R\&D spending. The results obtained show that - for the selected countries - the implemented $\mathrm{R} \& \mathrm{D}$ policies at both the EU and national level are not effective enough to cause economic growth.

In addition, increased economic growth does not seem to necessarily mean increased R\&D investment either. This may be good news for European countries which are currently experiencing very low (or even negative) GDP growth rates. According to our findings, the current economic crisis scenario, which affects some countries more than it affects others, will not necessarily contribute to deepen science and R\&D asymmetries among them. A few years need to go by before we can verify it.

\section{References}

Barbosa, N. and Faria, A.P. (2011) Innovation across Europe: How important are institutional differences? Research Policy, 40, 1157-1169.

Bravo-Ortega, C. and Marín, A.G. (2011) R\&D and Productivity: A Two Way Avenue? World Development, 39, 1090-1107.

Cavalcanti, T. and Novo, A. (2005) Institutions and economic development: How strong is the relation? Empirical Economics, 30, 263-276.

Coada, A. and Rao, R. (2008) Firm growth and R\&D expenditure. Economics of Innovation and New Technology 19, $127-145$.

Dickey, D.A. and Fuller, W.A. (1981) Likelihood ratio statistics for autoregressive time series with a unit root. Econometrica 49, 1057-1072.

Doornik, J.A. and Hansen, H. (2008) An Omnibus test for univariate and multivariate normality. Oxford Bulletin of Economics and Statistics 70, 927-939.

Ejermo, O., Kander, A. and Henning, M.S. (2011) The R\&D-growth paradox arises in fast-growing sectors, Research Policy 40, 664-672.

Engle, R.F. and Granger, C.W.J. (1987) Co-integration and error correction: Representation, estimation and testing. Econometrica 55, 251-276.

Ertur, C. and Koch, W. (2011) A contribution to the theory and empirics of Schumpeterian growth with worldwide interactions. Journal of Economic Growth 16, 215-255.

Franses, P.H., and Haldrup, N. (1994) The effects of additive outliers on tests for unit roots and cointegration. Journal of Business and Economic Statistics 12, 471-478.

Granger, C.W.J. (1988) Some recent developments in a concept of causality. Journal of Econometrics 39, 199-211. 
Johansen, S. (1991) Estimation and hypothesis testing of cointegration vectors in gaussian vector autoregressive models. Econometrica 59, 1551-1580.

Johansen S. and Juselius K. (1990) Maximum likelihood estimation and inference on co-integration with applications to the demand for money. Oxford Bulletin of Economics and Statistics 52, 169-210.

Jones, C. (1995) R\&D based models of economic growth. Journal of Political Economy 103, 759-84.

Lucas R. (1988) On the mechanics of economic development. Journal of Monetary Economics 22, 3-42.

MacKinnon, J.G. (1996) Numerical distribution functions for unit root and co-integration tests. Journal of Applied Econometrics 11, 601-618.

MacKinnon, J.M., Haug, A. and Michelis, L. (1999) Numerical distribution functions of likelihood ratio tests for cointegration. Journal of Applied Econometrics 14, 563-777.

Romer, P. (1986) Increasing returns and long-run growth. Journal of Political Economy 94, 1002-1037.

Scopelliti, A.D. (2010) Competition and economic growth: A critical survey of the theoretical literature. Journal of Applied Economic Sciences 5, 70-93.

Tavares, J. (2004) Institutions and economic growth in Portugal: A quantitative exploration. Portuguese Economic Journal 3, 49-79.

Teixeira, A. (2007) How has the Portuguese innovation capability evolved? Estimating a time series of the stock of technological knowledge (1960-2001). Portuguese Journal of Social Science 6, 77-96.

Teixeira, A. and Fortuna, N. (2004) "Human capital, innovation capability and economic growth in Portugal, 1960 2001". Portuguese Economic Journal 3, 205-225.

Teixeira, A., and Fortuna, N. (2010) Human capital, R\&D, trade, and long-run productivity: Testing the technological absorption hypothesis for the Portuguese economy in 1960-2001. Research Policy 39, 335-50.

Wu, Y., Zhou, l., and Li, J. (2007) Co-integration and causality between R\&D expenditure and economic growth in China: 1953-2004. International Conference on Public Administration, 869-76. 